\title{
GREEN BANKING: AN INDISPENSABLE STEP FOR THE BANK TO SAVE OUR ENVIRONMENT
}

\author{
Noorjahan Begum \\ Lecturer \\ Dept. of BBA
}

CCN University of Science \& Technology, Bangladesh

Md. Mazharul Islam Bhuiyan

Lecturer

Dept. of BBA

CCN University of Science \& Technology, Bangladesh

Nushrat Hashmi

Lecturer

Dept. of Mathematics

CCN University of Science \& Technology, Bangladesh

Nayan Kumar Sadhu

Lecturer

Dept. of BBA

CCN University of Science \& Technology, Bangladesh

Md. Ali Imran

\section{Lecturer}

Dept. of BBA

CCN University of Science \& Technology, Bangladesh

\section{Abu Obida Rahid}

\section{Lecturer}

Dept. of BBA

CCN University of Science \& Technology, Bangladesh

\section{Ikbal Ahmed}

Lecturer

Dept. of CSE

CCN University of Science \& Technology, Bangladesh

Received: August 01, $2021 \quad$ Accepted: August 15, $2021 \quad$ Online Published: August 20, 2021

DOI: $10.46545 /$ aijbms.v3i1.146 


\begin{abstract}
This research aims at keeping our planet safe which we are harming day by day by the advancement of modern civilization. In modern age, we are now vastly dependent on bank sector for our important activities. As a result, banks in Bangladesh are performing digitalize and effective activities to maintain a sound economy due to emphasize public services for profits. In this study the authors found that profit should not be earned at the expense of the world's most pressing environmental problem which can be caused a climate change through global warming. Western countries have already thought out of the box and introduced green banking for sustainable development. Sampling framed and statistical tools used by researchers and reveals that green banking $(G B)$ is not only corporate social responsibility (CSR) but also in broader sense of corporate environmental responsibility (CER). It also explains the main objective of green banking is to keep the world livable without any significant damage. Specifically, we already have seen the light. But we have to adopt this idea for all commercial Bank either public or private.
\end{abstract}

Keywords: Green Banking, Corporate Social Responsibility, Corporate Environmental Responsibility, Sustainable development, Global warming.

\title{
INTRODUCTION
}

Nowadays climate change is the alarming issue and we are facing an alarming situation. The Earth's environment is being polluted in different forms which caused harms to the Earth, resulting rapid change of the Earth's climate for the development of civilization. Therefore, living creatures are confronting intense danger for their existence. Banks cannot avoid the liability of environmental pollution. We have to find out the way to overcome these circumstances through bank. Bank should introduce green innovation products and reducing projects which are not environment friendly for focusing to decrease the carbon emission. It is high time to think about Corporate Environmental Responsibility (CER) which is wider than Corporate Social Responsibility (CSR). Green banking is promoting as eco-friendly banking practices by combining its operational improvements and technology know-how in banking operations. It helps not only decrease of internal carbon footprint but also reduction of external carbon emission. Bangladesh Bank developed Green Banking Policy in 2011 as well as it has already provided technical support for Green Banking adaptation. Green Banking helps both advances their own initiative and socially responsible behavior of other business. Its activities include using all of the banks resources with responsibility and care and its main aims to avoid waste, less paper intensive, fully automation and give priority to choices that take sustainability into account.

\section{LITERATURE REVIEW}

Marcel Jeucken identified four steps of action that banks could take for sustainability in his book "Sustainable Finance and Banking", 2001. Defensive banking, preventative banking, aggressive banking, and sustainable banking are the four stages. The first three terms are described as banking's stages or attitudes toward environmental issues. In reality, his research is a forerunner in the field of green or socially responsible banking.

Thombre (2011) researched the "New Face of Banking: Green Banking." The effect of a bank's external activities on the economy is enormous, but impossible to quantify.

Green Banking, according to Bihari (2011), entails increasing corporate social responsibility (CSR). It all begins with the goal of environmental protection, with banks determining if a proposal is environmentally sustainable and has some long-term effects before 
funding it. Only after the public safety requirements are met can a corporation be granted a loan. Green banking may be done effectively with the help of technologies and strategy.

According to Verma (2012), Indian banking is increasingly realizing the need for a change from the profit, profit, profit motive to the 'planet, citizens, and profit' motive. Banks should lead the way in implementing green banking for long-term growth.

Global change, which is one of the most researched and debated topics, has the greatest effect on the planet's atmosphere as a whole. (Green Banking Policies of Bangladesh Bank)

Green Banking in Bangladesh: A Comparative Analysis was the subject of Md. Maruf Ullah's (2013) study. Banks agree that any small "GREEN" effort taken today can help to create a greener world, and that each of them will contribute to a healthier global climate. Overall, green banking is a great opportunity for citizens to become more aware of global change.

Chowdhury and Dey (2016) have performed a study to analyze the green banking practices in Bangladesh. They reported that Bangladesh Bank has simplified green banking by policy and strategy formulation and allocation of budget for green initiatives. They also reported the slow growth of green projects financing and proposed special packages for growth.

Chen, Hossen, Muzafary, and Begum, (2018) have identified that the Bank is a perpetual member of the economy because it is possible to work on a business relationship between rich and viable life practices. The groups play an indispensable role in this dramatic game such as Brickfield, machine, paper, grammar school, business appraisers, directors, angry procedures and so on. Carbon dioxide is polluted in the future environment.

Masud, Kaium, Hossain, and Kim (2018) Climate change is the most urgent issue in the global context. Bangladesh is in the most vulnerable situation. Bangladesh will go through significant losses if the situation does notchange. The assessment is that by 2050 , the annual loss will be $2 \%$ and the gross domestic product $9.4 \%$ (GDP) by 2050 and 2100 , while the country is liable for less than $0.35 \%$ of global carbon emissions.

Hoque, Mowla, Uddin, Mamun, and Uddin (2019) conducted research to determine the state of green banking practices among Bangladesh's non-bank financial institutions (NBFIs) and commercial banks. The author noticed that most banks and NBFIs conduct green banking on a small scale and have no detail about it in their annual reports and websites.

\section{OBJECTIVES OF THE STUDY}

Developed countries are living in harmony by sacrificing biosphere. Though Bangladesh has smallest involvement in industrialization but she is victim of world environment pollution. There is no profit of this progress of the civilization or advancement if there is no planet. The basic objectives regarding green banking are as follows:

- To analyze the practices of green banking in Bangladesh;

- To promote environment friendly financing in the industry/project/business sector

- To justify the prospects and problems of green banking practices in Bangladesh

- To ensure the use of organizational resources in favor of the environment and society; and

- Finally, to suggest recommendation for policy implication.

\section{METHODOLOGY OF THE STUDY}

The research is focused on a literature analysis as well as secondary data sources. Secondary data was gathered from Bangladesh Bank websites from 2017 to 2019 as well as eight selected commercial banks' websites and reviews, among other sources. In addition, material is gathered from the company's business profile, daily journals, and numerous seminars and workshops. Any 
knowledge was also gathered from 'YouTube.' In addition, several papers and publications were examined in order to broaden the scope of the research. The information is studied using statistical data in terms of green banking policies and issues in Bangladesh. We have looked at when and how banks are implementing green banking activities.

\section{LIMITATION OF THE STUDY}

- The major limitation of the study is that no primary data is involved in the study.

- The data was not found in a structure way.

- It was very difficult to get the full information due to maintaining confidential purpose.

PRESENT SITUATION ON GREEN BANKING IN BANGLADESH

Green banking is a form of banking from which the country gets sound environment. Bangladesh Bank is pioneer bank which has ins and outs information on it to execute 'Green Banking'. Four refinance scheme of low interest launched by Bangladesh Bank for environment friendly factories. It means developing and promoting environmental friendly by some of the following steps which can be taken for going green in banking:

\begin{tabular}{|l|l|}
\hline 1) Online banking & 6) Green Loans \\
\hline i) Paying bills online & 7) Green Debit Cards/ Credit Cards \\
\hline ii) Remote deposit/ bKash & 8) Mobile Banking \\
\hline iii) Online Fund Transfer & 9) Green Building \\
\hline iv) Electronic Statement & 10) Green Mortgage \\
\hline v) Automated Clearing House & 11) Save papers \\
\hline 2) Green Accounts (Solar ATM Service) & 12) Roof Gardening \\
\hline 3) Green Financing & 13) Bio gas plant \\
\hline 4) Power Saving Equipment's & 14) Waste management \\
\hline 5) Green Marketing & 15) Green Bond \\
\hline
\end{tabular}

Online banking: It is optimist news that at the end of Fiscal Year 2018, 57 banks have online branches out of 57 banks. Bangladesh Bank encourages to the banks that establish branches to assured maximum use of solar energy.

Table 1. Online Banking Coverage

\begin{tabular}{|l|c|c|c|}
\hline \multicolumn{1}{|c|}{ Particular } & Fiscal Year 2017 & Fiscal Year 2018 & Fiscal Year 2019 \\
\hline $\begin{array}{l}\text { Banks activity through } \\
\text { online branches }\end{array}$ & $75.10 \%$ & $87.35 \%$ & $89.50 \%$ \\
\hline $\begin{array}{l}\text { No. of branches powered } \\
\text { by solar energy }\end{array}$ & 500 & 546 & 572 \\
\hline
\end{tabular}

Source: Annual reports of the Bangladesh Bank, 2017-2019.

Electronic Payment: Interbank facilities electronic payments originating from various payments channel such as Green Card, Automated Teller Machine (ATM) and Point of Sale (POS). 
Nowadays 53 banks out of 57 banks are functioning card business, 51 banks operating interbank Automated Teller Machine (ATM) transaction and 51 banks implementing Point of Sale (POS) transaction in Bangladesh.

Table 2. Electronic Payment Coverage

\begin{tabular}{|c|c|c|c|}
\hline Terminal & As on 30 June 2017 & As on 30 June 2018 & Growth \% \\
\hline Card & $1,19,43,650$ & $1,37,34,605$ & 1.0 \\
\hline ATMs & 9,246 & 9,747 & 5.4 \\
\hline POS & 36,288 & 41,130 & 13.3 \\
\hline
\end{tabular}

Source: Payment Systems Department, Bangladesh Bank, Annual Report 2017-2018.

Table 3. Electronic Payment Coverage

\begin{tabular}{|c|c|c|c|}
\hline Terminal & As on 30 June 2018 & As on 30 June 2019 & Growth \% \\
\hline Card & $1,37,34,605$ & $1,72,39,902$ & 25.5 \\
\hline ATMs & 9,747 & 10,722 & 10.0 \\
\hline POS & 41,130 & 52,846 & 28.5 \\
\hline
\end{tabular}

Source: Payment Systems Department, Bangladesh Bank, Annual Report 2018-2019.

Table 4. Direct Green Financing in FY18 (Fiscal Year 2018)

\begin{tabular}{|c|c|c|c|c|c|c|c|c|}
\hline & & & & & & & \multicolumn{2}{|c|}{ In Million Taka } \\
\hline$\stackrel{\text { Types of Bank/FI }}{\longrightarrow}$ & \multirow[t]{2}{*}{$\begin{array}{l}\text { SCBs } \\
(06)\end{array}$} & \multirow{2}{*}{$\begin{array}{c}\text { DFI } \\
\mathrm{s} \\
(02)\end{array}$} & \multirow[t]{2}{*}{$\begin{array}{c}\text { PCBs } \\
(40)\end{array}$} & \multirow[t]{2}{*}{$\begin{array}{c}\text { FCBs } \\
(09)\end{array}$} & \multirow[t]{2}{*}{$\begin{array}{c}\text { Bank's } \\
\text { Total }\end{array}$} & \multirow[t]{2}{*}{$\begin{array}{l}\text { FIs } \\
(34)\end{array}$} & \multirow[t]{2}{*}{$\begin{array}{l}\text { Grand } \\
\text { Total }\end{array}$} & \multirow{2}{*}{$\begin{array}{c}\% \text { of } \\
\text { Total } \\
\text { Green } \\
\text { Finance }\end{array}$} \\
\hline $\begin{array}{l}\text { Category of Green } \\
\text { Finange }\end{array}$ & & & & & & & & \\
\hline Renewable Energy & 25.5 & 7.7 & 2605.9 & 192.6 & 2831.7 & 523.9 & 3355.6 & $4.7 \%$ \\
\hline Energy Efficiency & 0.0 & 0.3 & 3156.0 & 0.0 & 3156.3 & 1080.6 & 4236.9 & $5.9 \%$ \\
\hline Alternative Energy & 0.0 & 0.0 & 9.0 & 0.0 & 9.0 & 0.0 & 9.0 & $0.0 \%$ \\
\hline $\begin{array}{l}\text { Waste } \\
\text { Management }\end{array}$ & 133.2 & 0.0 & 34914.6 & 0.0 & 35047.8 & 308.8 & 35356.6 & $49.6 \%$ \\
\hline $\begin{array}{l}\text { Recycling \& } \\
\text { Recyclable Product }\end{array}$ & 271.8 & 0.0 & 3471.3 & 0.0 & 3743.1 & 124.1 & 3867.2 & $5.4 \%$ \\
\hline $\begin{array}{l}\text { Green Brick } \\
\text { Manufacturing }\end{array}$ & 821.7 & 36.0 & 9571.4 & 0.0 & 10429.2 & 560.1 & 10989.2 & $15.4 \%$ \\
\hline $\begin{array}{l}\text { Green } \\
\text { Establishment }\end{array}$ & 280.8 & 0.0 & 10331.0 & 0.0 & 10611.7 & 658.3 & 11270.0 & $15.8 \%$ \\
\hline Misc. & 282.2 & 1.5 & 1845.1 & 0.0 & 2128.8 & 133.8 & 2262.6 & $3.2 \%$ \\
\hline Total & 1815.2 & 45.4 & 65904.3 & 192.6 & 67957.5 & 3389.6 & 71347.2 & $100 \%$ \\
\hline
\end{tabular}

Source: Sustainable Finance Department, Bangladesh Bank Annual Report 2017-2018. 
Table 5. Direct Green Financing in FY19 (Fiscal Year 2019)

\begin{tabular}{|c|c|c|c|c|c|c|c|c|}
\hline & & & & & & & \multicolumn{2}{|c|}{ In Million Taka } \\
\hline$\stackrel{\text { Types of Bank/FI }}{\longrightarrow}$ & \multirow[t]{2}{*}{$\begin{array}{l}\text { SCBs } \\
(06)\end{array}$} & \multirow{2}{*}{$\begin{array}{c}\text { DFI } \\
\text { s } \\
(02)\end{array}$} & \multirow[t]{2}{*}{$\begin{array}{c}\text { PCBs } \\
(40)\end{array}$} & \multirow[t]{2}{*}{$\begin{array}{c}\text { FCBs } \\
(09)\end{array}$} & \multirow[t]{2}{*}{$\begin{array}{l}\text { Bank's } \\
\text { Total }\end{array}$} & \multirow[t]{2}{*}{$\begin{array}{l}\text { FIs } \\
(33)\end{array}$} & \multirow[t]{2}{*}{$\begin{array}{c}\text { Grand } \\
\text { Total }\end{array}$} & \multirow{2}{*}{$\begin{array}{c}\% \text { of } \\
\text { Total } \\
\text { Green } \\
\text { Finance }\end{array}$} \\
\hline $\begin{array}{l}\text { Category of Green } \\
\text { Finange }\end{array}$ & & & & & & & & \\
\hline Renewable Energy & 15.35 & 2.81 & 1921.36 & $\begin{array}{c}216.5 \\
7\end{array}$ & 2156.08 & $\begin{array}{c}1286.3 \\
4\end{array}$ & 3442.43 & $3.3 \%$ \\
\hline Energy Efficiency & 0.0 & 0.0 & 3667.96 & $\begin{array}{c}130.8 \\
3\end{array}$ & 3798.78 & 232.81 & 4031.59 & $3.8 \%$ \\
\hline Alternative Energy & 0.0 & 0.0 & 83.98 & 0.0 & 83.98 & 0.0 & 83.98 & $0.1 \%$ \\
\hline $\begin{array}{l}\text { Waste } \\
\text { Management }\end{array}$ & 216.70 & 0.0 & $\begin{array}{c}25571.3 \\
5\end{array}$ & $\begin{array}{c}128.0 \\
5\end{array}$ & $\begin{array}{c}25916.1 \\
0\end{array}$ & $\begin{array}{c}1443.3 \\
0\end{array}$ & $\begin{array}{c}27359.4 \\
0\end{array}$ & $25.9 \%$ \\
\hline $\begin{array}{l}\text { Recycling \& } \\
\text { Recyclable Product }\end{array}$ & 253.68 & 0.0 & $\begin{array}{c}10852.6 \\
0\end{array}$ & 2.40 & $\begin{array}{c}11108.6 \\
8\end{array}$ & 130.00 & $\begin{array}{c}11238.6 \\
8\end{array}$ & $10.7 \%$ \\
\hline $\begin{array}{l}\text { Green Brick } \\
\text { Manufacturing }\end{array}$ & 726.92 & 0.0 & $\begin{array}{c}16172.2 \\
7\end{array}$ & 0.0 & $\begin{array}{c}16899.1 \\
9\end{array}$ & $\begin{array}{c}1686.7 \\
3 \\
\end{array}$ & $\begin{array}{c}18585.9 \\
2\end{array}$ & $17.7 \%$ \\
\hline $\begin{array}{l}\text { Green } \\
\text { Establishment }\end{array}$ & 0.00 & 0.0 & $\begin{array}{c}13878.2 \\
1 \\
\end{array}$ & $\begin{array}{l}1873 \\
5.31 \\
\end{array}$ & $\begin{array}{c}32613.5 \\
2 \\
\end{array}$ & $\begin{array}{c}1689.6 \\
9 \\
\end{array}$ & $\begin{array}{c}34303.2 \\
1 \\
\end{array}$ & $32.6 \%$ \\
\hline Misc. & 6.79 & 0.75 & 6169.16 & 0.0 & 6176.70 & 31.00 & 6207.70 & $5.9 \%$ \\
\hline Total & $\begin{array}{c}1219.4 \\
4\end{array}$ & 3.56 & $\begin{array}{c}78316.8 \\
8\end{array}$ & $\begin{array}{l}1921 \\
3.16\end{array}$ & $\begin{array}{c}98753.0 \\
4\end{array}$ & $\begin{array}{c}6499.8 \\
7\end{array}$ & $\begin{array}{c}105252 . \\
91\end{array}$ & $100 \%$ \\
\hline
\end{tabular}

Source: Sustainable Finance Department, Bangladesh Bank Annual Report 2018-2019.

\section{Environment friendly industry/ project/business}

Bangladesh Bank which is a guardian of all banks in Bangladesh helps to other commercial banks to adapt green banking. If the industry/project/business is environment friendly then they sanction the loan for their industry/project/business operations. Before making financing decision banks should take up environmentally responsible financing; weighting up environmental risks of project, and specifically supporting and cultivating development of forthcoming green initiatives and projects. It will minimize the structural cost of an industry/ project/business.

\section{PROSPECTS AND PROBLEMS OF GREEN BANKING PRACTICE IN BANGLADESH}

Prospects or anticipation of green banking: Plethora of prospects of green banking focuses new era in banking sector. Now these are discussed in below-

- Creating public awareness: Banks or financial institution arranged different programs like seminar, symposium, road show etc. to educate their personnel, clients, general public regarding the environmental issues.

- Green banking financing product: Innovation of different types of product in green banking are new era which are prospects of green banking in Bangladesh.

- Paperless banking: It is encouraging that a large number of banks have already adopted paperless banking with varying degree of adoption. It is recommended that those who have not adopted paperless banking they should have adopt it immediately.

- Proper evaluation: Commercial bank should scrutinize projects profiles in terms of scale, nature and the magnitude of potential negative and positive environmental impacts. There 
should be formal environmental and social risk policy to govern lending activities. Banks should also apply quantitative approach for environmental risk rating.

- Post transaction monitoring: During the project execution and operations phases, banks must track post-lending output to ensure the best ERM (Environmental Risk Management) scheme. Physical assessments of the manufacturing process should be conducted, as should the planning of a training curriculum, the determination of environmental liability, and the implementation of audit schemes, among other things.

Problems or challenges of green banking: There are some major problems ahead for green banking in Bangladesh. These are as follows-

- Lack of knowledge: Lack of proper knowledge about technology is main problem of green banking.

- Lack of skill: Employees are not skillful. So they are not well trained up about green banking.

- Lack of timely evaluation: Timely evaluation is necessary for all organization, business or any institutions. Proper evaluation can helps to get the exact result of the firm.

- Lack of paperless banking: In banking system, banks are still following the traditional of using paper for various transactions where it is no necessary adopting the Green Banking.

- Lack of carbon credit business: To safeguard the atmosphere, both nations are required to reduce greenhouse gas emissions and carbon emissions under the Kyoto Protocol. The gas emissions must be certified through Qualified Pollution Reductions (CERs), also known as carbon Credit Corporation, where banks are unable to follow any of these ecofriendly systems.

- Poor long run sustainable investment: Investment with favorable impact on environment needs long run financing and usually has low rate of return. As a result this type of investment is not popular with the investors.

- Lack of innovative green product: The sample banks through their research and development are not exploring the diversified eco-friendly products to be offered to the potential loanees.

- Lack of infrastructural facilities for managing environmental risk: Some banks have not yet developed any administrative set up to train up their employees to meet the environmental challenges arising out of advancing loans and financing environment sensitive projects.

- Equators principle: Banks or financial institutions are running behind similar organization in other countries regarding compliance with standards set for them. Bangladeshi banks or financial institutions are neither has adopted equators principle nor are signatory to the United Nations Environment Programme Finance Initiative (UNEPFI).

- Lack of creating public awareness: Banks and financial institutions have not held any seminars, symposiums, or road shows to teach their employees, customers, or the general public about environmental concerns. There should be an ongoing discussion with relevant stakeholders on environmental issues.

\section{Ensure the use of organizational resources}

Green banking concentrates all banks internal operation by going green. Utilizing maximum renewable energy, automation and other measures to minimize carbon footprint and so on should adopt in an efficient manner. Online correspondence ought to be widely utilized for office 
management where possible. To save paper, employee should printing double side and also use one side spare paper as notepads. Establishment of vitality proficient electronic as well as artificial intelligence equipment's such as automatic shutdown of computers, fans, lights, air coolers etc. will help decline electricity consumption. Instead of normal bulbs of the banks, energy saving bulbs should introduce. Banks should give priority to use solar energy in the workplace. Bank should find a way to spare vitality from corporate business make a trip and urge representatives to buy energy efficient cars (that consume less fuel) can reduce gas and petroleum consumption (Bangladesh Bank Policy guidelines for green banking).General instructions are given to the employees of the banks to use their limited resources for maximum output.

\section{FINDINGS}

- Essentially, green banking cuts paper work, lowers costs, eliminates threats, saves time, improves reputation, and maintains a safe climate. If a paperless banking method is implemented for families, it is projected that 16500000 trees would be saved per year. Almost every bank in Bangladesh has begun to conduct online transactions in order to take advantage of emerging technologies. While a significant number of Private Commercial Banks (PCBs) and Foreign Commercial Banks (FCBs) in Bangladesh have introduced green banking policies, the number of State-owned Commercial Banks (SCBs) and Specialized Development Banks is steadily growing (SDBs).

- The Bangladesh Bank not only offers appropriate strategies, but also technological assistance for green banking adoption. The Central Bank has stated that proposals that are environmentally sustainable would receive additional or reduced funding, while projects that are not environmentally friendly would not receive any assistance. In 2016, the Bangladesh Bank established a fund of 200 million dollars to sustain a safe working atmosphere in factories and ensure protection in the readymade apparel, leather, and plastic sectors, but only 42 million dollars were disbursed in September of 2019.

- Owing to a lack of understanding regarding current technologies and systems, bank management and other involved parties are less interested in adopting green banking. They carry out their banking operations based on their previous experience and expertise. As a consequence, they permanently lose their consumer appeal because modern consumers are used to receiving prompt service.

- Solar Equipment's, Effluent Treatment Plants (ETPs), Bio-gas Plants, and Hybrid Hoffman Kilns (HHKs) are examples of green banking initiatives.

- Banks' implementation of various current Green Banking laws is also, to a large degree, willful. In Bangladesh, the essence of bank management activities is eco-friendly banking practices, which are given less priority by the general public since they are not deemed obligatory.

- Since they have a small variety of green products for their customers, most banks in Bangladesh have followed the Credit Risk Management (CRM) credit evaluation and management system, which does not have any risk requirements.

- Online banking and Automated Teller Machine (ATM) services are seen as the first step toward introducing paperless work, putting the community and community first, and ensuring long-term growth. However, the majority of State-owned Commercial Banks (SCBs) and Specialized Development Banks (SDBs) continue to practice weak online banking, and ATM facilities are still inadequate. 


\section{DISCUSSION}

Bank can play a vital role to ensure sound environment by taking the blessing of modern technology. The importance of green banking is immense in economy to reduce costs and helps to avoid risks, and to enhance customer satisfaction by delivering rapid services. The challenges of green banking are new concept for many banks, involvement of higher operating cost, necessity of experienced officer, reputational risk which may arise for choosing environmental damaging projects and involvement of higher credit risk. So, the respective problem facing banks need to handle the above challenges by following the Bangladesh Bank's guidelines effectively regarding green banking policy and empowering charismatic leading system. All banks should maintain proper training systems and keep critical problem-solving tendency to adapt green banking systems in their organization rapidly. Bangladesh Bank should carefully monitor and supervise the green banking practices in all banks. From the study of findings, we observed that State-owned Commercial Bank (SCBs) and Specialized Development Bank (SDBs) have not fully taken the green banking policy, though Bangladesh Bank have taken initiatives to adapt it for all types of banks. This finding partially supports existing literature that real scenario of green banking is growing steadily. Slow increasing adaptation of green banking is pessimism because the banks are perpetual members of a country. Bangladesh Bank made a fund for environment friendly project but only $21 \%$ was disbursement till last 3 years. Bank management have less interested on lending principle of green initiative projects.

At present all banks urgent need to enhance knowledge \& awareness about business technology so that we can make our business environment human friendly. Government should encourage to all general people about the advantages of green banking system by providing necessary information in various social media.

\section{RECOMMENDATION}

- Green banking regulations must be followed by all schedule banks in accordance with the Bangladesh Bank's green banking guidelines. As a result, State-owned Commercial Banks (SCBs) and Specialized Development Banks (SDBs) would effectively implement green banking.

- The Bangladesh Bank must keep track of all banks' green banking activities and take corrective action to assign budgets to environmentally sustainable sectors. A database may be created for professional assistance as well.

- It is important that all relevant bodies work together. Knowledge networking is the most effective and beneficial method for peer groups.

- Authorities must make every effort to develop the most critical measures in the banking sector. As a result, green banking presents customers with a strong understanding of the economy as well as environmentally sustainable corporate practices. Through funding more and more environmentally sustainable schemes, banks can ensure that funds are available for projects that are environmentally friendly or ethical in nature.

- Hybrid Hoffman Kiln (HHK) projects.

○ Green Bond

- Green Savings Account

- Green Mortgages

- Green credit cards

○ Mobile banking and online banking

○ Hybrid Hoffman Kiln (HHK) projects. 
- Government should take appropriate steps to make conscious common people about importance of eco-friendly smart banking. Uses of papers is leading to the environment to destruction by encourage flattening of plants. To keep our environment green banks should reduce the use of papers or begin the use of eco-friendly papers. Representatives should minimize unnecessary printing and use flip over while printing.

- Assessing environment risk essential for bank to invest in a project. Banks should monitor existing environment friendly products and introduce new environment friendly products such as

$\circ$ Green Home Loan,
$\circ$ Green Car Loan
$\circ$ Auto Brics industry
$\circ$ LPG bottoling Plant
$\circ$ Solar home system
$\circ$ Effluent Treatment Plant (ETP)
$\circ$ Bio gas plant
$\circ$ Bio fertilizer plant

- Deposits are one of the main functions of bank. Banks give lucrative deposit services to collect money from the clients. Banks should be introducing environment friendly deposit products under online management.

- Alternative Delivery Channels (ADC) should be introduced in all schedule banks. It expands the reach of services beyond the traditional bank branch channel. So State-owned Commercial Banks (SCBs) and Specialized Development Banks (SDBs) should practice Alternative Delivery Channels appropriately.

- Banks can play a vital role in against natural disasters. Banks can provide financial supports, aids and interest free loans and so on after such differing circumstance to support the sufferers to survive in the newer environment. Several seminar and symposium on environmental pollution arranged by banks may make their clients more conscious to adapt green banking activities.

\section{CONCLUSION}

In today's financial landscape, green banking has become a hot topic. Green banking operations, both in theory and in reality, are updated with the help of bank management. Both scheduled banks must now not only allocate budget for green financing, green events or green initiatives as part of their corporate social responsibility (CSR) operations, green promotion, and capacity building, but also ensure that the budget allocation is used efficiently. Bangladesh Bank has the regulatory authority to audit commercial banks to see whether they are following green banking policies in order to combat the country's own emissions. Green banking is thought to ask for capital in the short term but provide long-term growth. Finally, the researcher believes that it is past time to strengthen green banking policies in the banking sector in order to promote the use of renewable, efficient energy from nature (GREEN).

\section{REFERENCES}

Bihari, S. C. (2011). Green banking-socially responsible banking in India. The India Banker, 6(1), 32-37.

Chowdhury, M. A. A., \& Dey, M. (2016). Green banking Practices in Bangladesh. The Cost and Management, 44(2), 34-39. 
Chen, Z., Hossen, M. M., Muzafary, S. S., \& Begum, M. (2018). Green banking for environmental sustainability-present status and future agenda: Experience from Bangladesh. Asian Economic and Financial Review, 8(5), 571.

Hoque, N., Mowla, M., Uddin, M. S., Mamun, A., \& Uddin, M. R. (2019). Green Banking Practices in Bangladesh: A Critical Investigation, International Journal of Economics and Finance, 11(3), 58-68.

Masud, M., Kaium, A., Hossain, M. S., \& Kim, J. D. (2018). Is green regulation effective or a failure: comparative analysis between Bangladesh Bank (BB) green guidelines and global reporting initiative guidelines. Sustainability, 10(4), 1267.

Thombre, K. A. (2011). The new face of banking: Green banking. Research Paper-Commerce, $1(2), 1-4$.

Ullah, M. S. (2014). Green Banking in Bangladesh: Progress, Problems and Prospects. NIBM, Prajnan, 43(1).

Verma, M. K. (2012). Green banking: a unique corporate social responsibility of India Banks. International Journal of Research in Commerce \& Management, 3(1), 110-114.

\section{Copyrights}

Copyright for this article is retained by the author(s), with first publication rights granted to the journal. This is an open-access article distributed under the terms and conditions of the Creative Commons Attribution license (http://creativecommons.org/licenses/by/4.0). 